\title{
Traumatismele organelor cavitare abdominale la copil, mecanisme de producere şi principii de tratament
}

\author{
Elena Țarcă', Irina Ciomaga², Nicolae Nistor ${ }^{2}$, Irina Crişcov², Tamara Solange Roşu ${ }^{3}$ \\ ${ }^{1}$ Disciplina de Chirurgie şi Ortopedie Pediatrică, Departament Chirurgicale II, Universitatea de \\ Medicină şi Farmacie „Gr. T. Popa“, Iaşi, România \\ ${ }^{2}$ Disciplina de Pediatrie, Departament Medicina Mamei şi a Copilului, Universitatea de Medicină şi \\ Farmacie „Gr. T. Popa“, Iaşi, România \\ ${ }^{3}$ Disciplina de Nursing, Departament Medicale II, Universitatea de Medicină şi Farmacie \\ "Gr.T. Popa", Iaşi, România
}

\begin{abstract}
REZUMAT
Traumatismele organelor cavitare abdominale reprezintă o cauză importantă de morbiditate la copil, după traumatismele cranio-cerebrale, vertebromedulare şi toracice, principalul mecanism de producere fiind accidentele rutiere, căderile accidentale cu impact pe abdomen sau accidentele sportive, agresiunile fizice şi exploziile. Dacă traumatismul abdominal a fost penetrant, cel mai frecvent va asocia o leziune de organ cavitar, pe când contuziile abdominale asociază mai adesea o leziune de organ parenchimatos, cu repercusiuni asupra stabilităţii hemodinamice. Investigaţiile imagistice şi paraclinice implicate în evaluarea unui traumatism abdominal cuprind radiografia toraco-abdominală în ortostatism, ecografia abdominală, lavajul peritoneal diagnostic, computer-tomografia abdominală şi laparoscopia exploratorie. Spre deosebire de traumatismele penetrante în cazul cărora explorarea chirurgicală este evidentă, la copiii mici cu contuzii abdominale leziunile organelor cavitare pot fi omise la momentul prezentării din cauza comunicării deficitare dintre pacient şi examinator, din cauza interpretării dificile a simptomatologiei în cazul asocierii şi a altor leziuni, precum şi din cauza absenţei iniţiale a semnelor ecografice de perforaţie. Întârzierea diagnosticului şi a tratamentului adecvat conduce la mărirea perioadei de spitalizare, a costurilor, dar şi a ratelor de morbiditate. Mortalitatea în cazul traumatismelor abdominale cu perforare de organ cavitar se situează în jurul ratei de $10 \%$, fiind cu atât mai mare cu cât leziunile digestive sunt multiple sau asociate cu alte traumatisme.
\end{abstract}

Cuvinte cheie: accident, copil, traumatism abdominal, perforaţie digestivă

\section{INTRODUCERE}

Traumatismele organelor cavitare abdominale reprezintă o cauză importantă de morbiditate la copil, după traumatismele cranio-cerebrale, vertebromedulare şi toracice, principalul mecanism de producere fiind accidentele rutiere, urmat de căderile accidentale cu impact pe abdomen, accidentele sportive, agresiunile fizice şi exploziile. Numărul pacienţilor pediatrici admişi în spital dupa traumatisme prin cădere de pe bicicletă a crescut, de asemenea, treptat. Copiii care suferă un impact direct al ghidonului de bicicletă au mai multe şanse de a necesita internare în unitatea de terapie intensivă pediatrică şi intervenţie chirurgicală abdominală comparativ cu cei căzuţi de la înălţime (1). Viscerele abdominale la copil sunt mai predispuse la leziuni traumatice în comparaţie cu adulţii din cauza musculaturii abdominale slab reprezentate, cuştii toracice elastice şi orizontalizării diafragmului. Dacă traumatismul abdominal a fost penetrant, cel mai frecvent va asocia o leziune de organ cavitar, pe când contuziile abdominale asociază mai adesea o leziune de organ parenchimatos, cu repercusiuni asupra stabilităţii hemodinamice. Trauma abdominală este prezentă la aproximativ $25 \%$ dintre paci- 
enţii pediatrici cu traumatisme majore şi este cea mai frecventă cauză a leziunilor letale nerecunoscute la copii (2). Un studiu retrospectiv pe un număr de peste 257.000 pacienţi cu traumatisme abdominale închise demonstrează o incidenţă de $0,3 \%$ a perforaţiilor colice şi de $1,1 \%$ a celor de intestin subţire, accidentele rutiere fiind cauza majoră a acestor traumatisme, urmată de agresiuni fizice, cădere de la înălţime, accidente sportive, industriale şi chiar manevra Heimlich (perforaţii gastrice atunci când stomacul este plin şi forţa de compresiune este prea mare) (3).

\section{Mecanisme de producere a leziunilor viscerelor abdominale}

Legislaţia rutieră cu obligativitatea purtării centurii de siguranţă a redus rata mortalităţii prin accidente de circulaţie, dar a crescut rata leziunilor organelor cavitare provocate de centura de siguranţă, prin mecanismul de decelerare şi din cauza compresiunii şi forţelor de sfâşiere (4). Multiplele interfeţe aer-ţesut de la nivelul tractului gastro-intestinal fac ca acesta să fie deosebit de vulnerabil la traumatisme, din cauza diferenţelor de impedanţă acustică. În momentul accidentului rutier, la nivelul abdomenului au loc o serie de mecanisme precum cel de accelerare-decelerare, compresiune, unde de stress şi forţe de sfâşiere, care împreună sunt responsabile de leziunile mezenterice, rupturile de aortă, leziunile organelor solide precum şi al celor cavitare. Forțele de compresiune directă asupra organelor cavitare sau strivirea acestora pe un corp dur (coloana vertebrală, centura de siguranţă) duc la creşterea bruscă a presiunii intraluminale şi ruptură prin explozie pe faţa antimezenterică, pe când forţele de decelerare vor provoca sfâşierea peretelui intestinal sau a mezenterului. Mai puţin frecvent dar posibil, leziunile viscerale pot fi cauzate de fragmente osoase care le perforează, în cazul asocierii fracturilor pelvine. Perforaţiile gastrice şi cele colice se manifestă rapid cu sindrom peritonitic din cauza iritaţiei produse de conţinutul gastric acid şi de încărcătura bacteriană ridicată, pe când perforaţiile jejunale se pot manifesta mai puţin zgomotos din cauza conţinutului alcalin şi a încărcăturii bacteriene mai reduse. În plus, simptomatologia poate fi modificată de prezența leziunilor asociate precum traumatisme toracice, craniene sau spinale, comă, şoc hipovolemic.

Traumatismele organelor intraabdominale provocate de accidente rutiere sunt bine cunoscute, perforaţiile intestinale fiind pe locul trei ca frecvenţă după leziunile hepatice şi cele splenice, fiind re- spectiv depistate în 5-16\% dintre cazurile de laparotomii efectuate pentru contuzii abdominale; perforaţiile rectale şi cele gastrice sunt mai rare, aproximativ $0,1-0,5 \%$, respectiv $0,02-1,7 \%(5,6)$. Frecvenţa scăzută a perforaţiilor gastrice după traumatisme abdominale închise se datorează protejării stomacului de către cuşca toracică, mobilităţii relative a organului, precum şi grosimii crescute a peretelui gastric. Localizarea perforaţiilor gastrice este pe peretele anterior în $40 \%$ dintre cazuri, pe marea curbură în $23 \%$ dintre cazuri şi pe mica curbură în $15 \%$, fiind adesea asociate cu leziuni ale altor organe, cel mai adesea leziuni splenice sau ale cuştii toracice (7). Duodenul, fiind un organ profund retroperitoneal, este rar sediul unor traumatisme, cel mai adesea reprezentate de contuzii parietale simple sau hematoame intramurale. Acestea din urmă se pot mări progresiv şi pot determina atât ocluzie mecanică, cât şi ischemie locală cu perforaţie ulterioară a peretelui şi peritonită secundară. În cazul unor traumatisme foarte grave se pot produce rupturi duodenale, atât intra-, cât şi retroperitoneale, asociate cu leziuni pancreatice, necesitând chiar duodenopancreatectomie cefalică. Foarte rar în literatura de specialitate, şi în special la adulți, sunt citate şi cazuri de leziuni posttraumatice de veziculă biliară, cu o incidenţă de $0,5 \pm 0,6 \%$ dintre toate leziunile viscerelor abdominale (8). Sindromul peritonitic, apărut la câteva zile dupa un traumatism abdominal, poate fi datorat si unei apendicite acute apărute atât din cauza traumatismului în sine, cât şi pe fondul depresiei imune ca urmare a stresului posttraumatic. Oricare ar fi cauza, sindromul peritonitic posttraumatic trebuie explorat chirurgical (9).

\section{PRINCIPII DE DIAGNOSTIC ŞI TRATAMENT}

Investigaţiile imagistice şi paraclinice implicate în evaluarea unui traumatism abdominal cuprind radiografia toraco-abdominală în ortostatism, ecografia abdominală, lavajul peritoneal diagnostic, computer-tomografia (CT) abdominală şi laparoscopia exploratorie. Vizualizarea radiologică a pneumoperitoneului pune rapid diagnosticul de perforaţie de organ cavitar (Fig. 1), dar evaluarea în dinamică a unui pacient cu semne radiologice negative iniţial poate depista la interval de 12-36 ore prezenţa pneumoperitoneului sau a unor niveluri hidro-aerice sugestive unui sindrom peritonitic secundar. Ecografia abdominală este o investigaţie neinvazivă, ieftină şi rapid disponibilă, care nu necesită sedare şi nici administrare de substanţă de contrast, având în acelaşi timp un grad ridicat de acurateţe în depistarea leziunilor abdominale trau- 


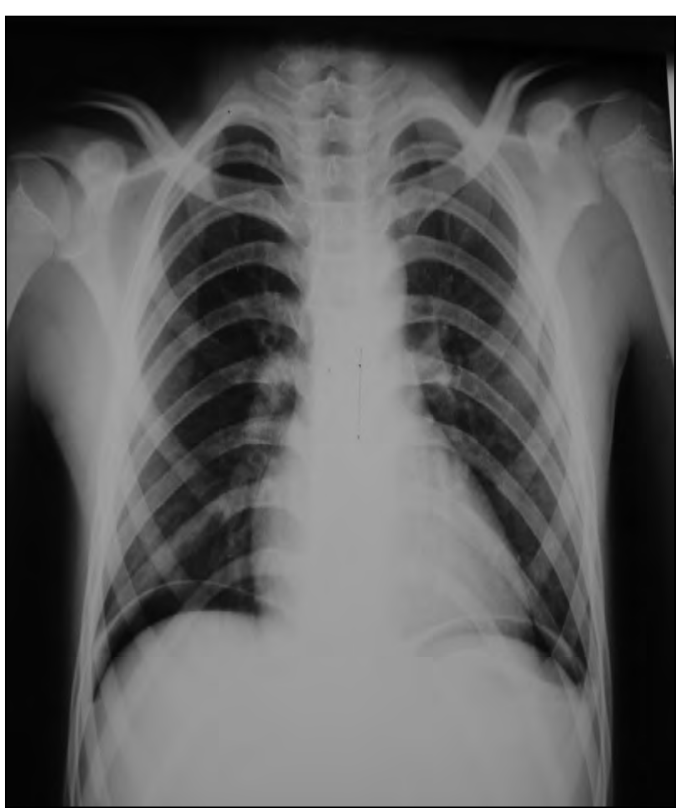

FIGURA 1. Pneumoperitoneu prin perforatie de organ cavitar

matice, în special al leziunilor organelor parenchimatoase şi în depistarea revărsatelor lichidiene peritoneale (10). Focused Assessment with Sonography for Trauma (FAST) poate detecta prezenţa fluidului liber sugestiv pentru leziuni intraabdominale. La copii însă, utilitatea FAST este limitată deoarece mai puţin de jumătate dintre pacienţii pediatrici cu leziuni abdominale au lichid liber (2). De asemenea, în prezenţa stabilităţii hemodinamice, depistarea ecografică a unei cantităţi de lichid liber intraperitoneal nu poate pune clar indicaţia de laparotomie (sânge sau conţinut digestiv?); în plus, leziunile mezenterice şi cele ale peretelui intestinal nu pot fi vizualizate direct ecografic. $\mathrm{Cu}$ o acurateţe de $86 \%$, o senzitivitate de $94 \%$ şi o valoare predictivă de $92 \%$, CT-ul abdominal poate depista atât perforaţiile, cât şi leziunile parţiale ale peretelui intestinal, precum şi leziunile mezenterice, acestea din urmă necesitând evaluare în dinamică din cauza potenţialului de evoluţie nefavorabilă în următoarele ore sau zile (11). Totuşi, CT-ul abdominal poate fi evitat la acei pacienti stabili hemodinamic, cu un scor Glasgow de 14-15, examen clinic abdominal normal şi un rezultat FAST negativ (12). Puncţia şi lavajul peritoneal în scop diagnostic sunt manevre relativ simple, pot depista un hemoperitoneu prin ruptură de organ parenchimatos sau o perforaţie intestinală prin punerea in evidenţă a revărsatului intestinal intraperitoneal, dar nu sunt specifice şi, în plus, sunt invazive, mai puţin practicate la copiii mici care nu cooperează, fiind înlocuite de CT-ul abdominal. Explorarea laparoscopică are marele avantaj de a preciza cu exactitate diagnosticul şi în acelaşi timp de a aspira, a spăla şi a sutura eventualele perforaţii intestinale unice, cu contaminare bacteriană minimă.

Prezenţa durerilor abdominale de tip peritonitic, a echimozei lineare caracteristice de la nivel abdominal, mai ales în cazul asocierii leziunilor pelvine sau a celor spinale lombare - ,sindromul centurii de siguranţă $\breve{c}^{\text {“ }}$, reprezintă o indicaţie clară de explorare a cavităţii peritoneale pentru depistarea leziunilor viscerale, chiar în prezenţa unor investigaţii imagistice aparent normale. Termenul de ,sindrom al centurii de siguranţă“" a fost pentru prima dată folosit de către Aiken în 1963 (13). De asemenea, la copii, prezenţa mărcii traumatice după lovitura de ghidon de bicicletă (Fig. 2) va ridica un înalt grad de suspiciune în privinţa leziunilor viscerale abdominale. Spre deosebire de traumatismele penetrante în cazul cărora explorarea chirurgicală este evidentă, la copiii mici cu contuzii abdominale, leziunile organelor cavitare pot fi omise la momentul prezentării din cauza comunicării deficitare dintre pacient şi examinator, din cauza interpretării dificile a simptomatologiei în cazul asocierii şi a altor leziuni, precum şi din cauza absenţei iniţiale a semnelor ecografice de perforaţie. Frecventă la adulţi, dar prezentă şi la pacienţii minori care fac parte din anumite categorii sociale defavorizate, intoxicaţia acută cu alcool etilic sau alte tipuri de droguri poate fi cauza producerii accidentului şi poate, de asemenea, masca simptomatologia dureroasă posttraumatică (14). Întârzierea diagnosticului şi a tratamentului adecvat conduce la mărirea perioadei de spitalizare, a costurilor, dar şi a ratelor de morbiditate (15).

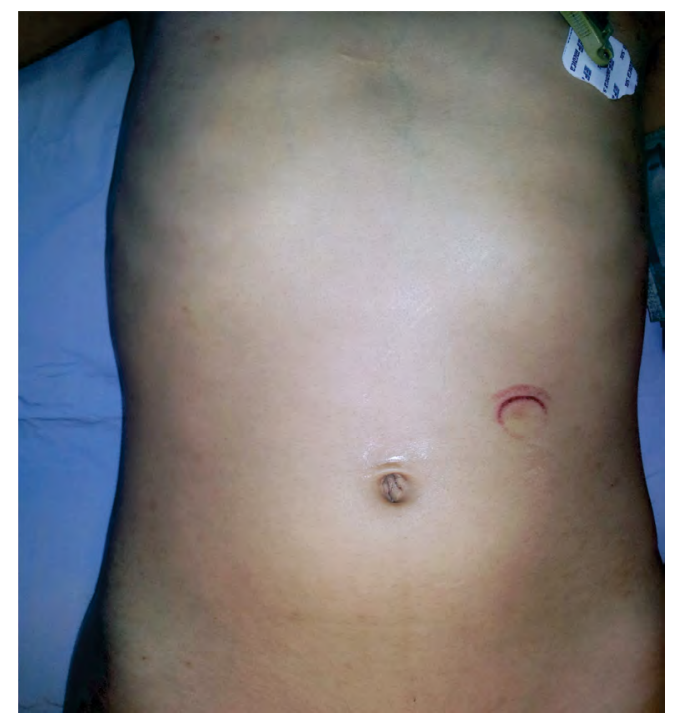

FIGURA 2. Marcă traumatică (ghidon de bicicletă) perforație jejunală

Managementul iniţial al pacienţilor în şoc traumatic include asigurarea a două linii venoase cen- 
trale (sau la nivelul membrelor superioare) şi administrarea în bolus de soluţii saline şi Ringer lactat. Dacă după al doilea bolus pacientul rămâne hipotensiv, este recomandată transfuzia sanguină (2). Managementul cazurilor fruste, cu durere abdominală de intensitate mică, stabile hemodinamic şi cu investigaţii imagistice normale va include spitalizare, examinări clinice repetate şi monitorizare biologică (hemogramă, transaminaze, sindrom inflamator, lactat, sumar de urină). Orice modificare în statusul pacientului va duce la repetarea investigaţiilor imagistice şi chiar intervenţie chirurgicală, leziunile cu manifestare tardivă precum hematoamele parietale sau mezenterice, care duc la ischemie şi perforare secundară nefiind rare (16). Spre deosebire de managementul leziunilor de organ parenchimatos, care este pe cât posibil conservator, tratamentul perforaţiilor organelor cavitare abdominale va fi unul chirurgical în urgenţă, din cauza riscului de peritonită şi sepsis. Scopul principal al tratamentului chirurgical este controlul rapid al sângerării şi al sursei de contaminare peritoneală, accentul fiind în schimb pus pe resuscitarea hidroelectrolitică, acido-bazică, corectarea hipotermiei şi a eventualei coagulopatii, restaurarea unei anatomii normale putând fi amânată dacă starea pacientului este gravă (17). Perforaţiile duodenale şi jejuno-ileale unice vor fi suturate într-un singur plan, pe când cele gastrice, colo-rectale sau vezicale în două planuri. Dacă leziunile sunt extinse sau multiple, sunt uneori necesare rezecţii intestinale şi anastomoze, iar pentru leziunile colice este uneori prudentă plasarea unei stome deasupra locului anastomozei. Tratamentul antibiotic este obligatoriu. Prevenirea unei hipertensiunii abdominale şi a sindromului de compartiment abdominal în cazul unor hematoame retroperitoneale mari sau a altor leziuni viscerale importante care necesită ,second look“ este posibilă prin lăsarea abdomenului deschis (laparostomie), dar mai ales prin plasarea unui sistem tip vacuum, care şi-a dovedit eficienţa şi chiar a îmbunătăţit rata supravieţuirii pe termen lung (18).

Perforaţiile de vezică urinară la copil sunt rare, aproximativ $0,05-2,0 \%$ dintre toate traumatismele pelvine, fiind adesea asociate cu fracturi de pelvis (19). La copiii foarte mici, vezica urinară este localizată intraperitoneal şi, la fel ca şi stomacul, ambele viscere cavitare cu eliminare prin orificiu îngust care nu permite evacuarea rapidă, sunt vulnerabile atunci când sunt pline, suferind un mecanism de explozie în momentul compresiunii bruşte între două planuri dure. Domul vezical este punctul slab, fiind cel mai adesea locul perforaţiei, urina acumu-

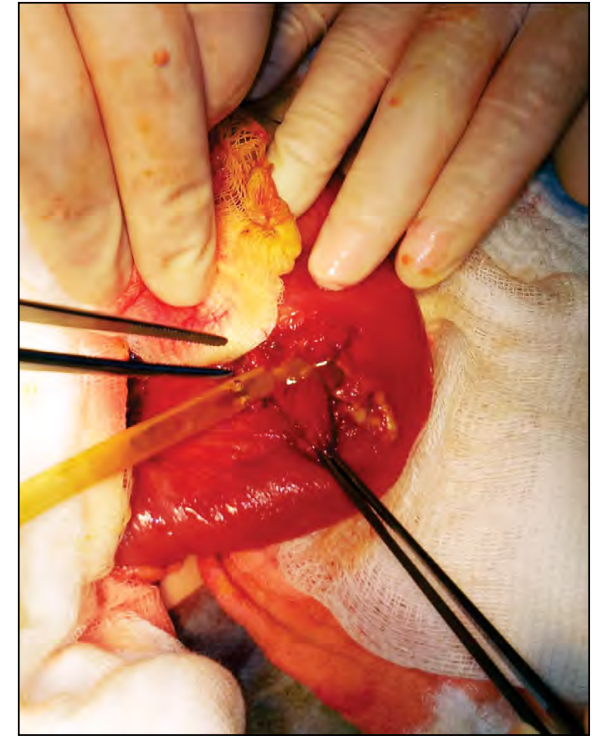

FIGURA 3. Perforație jejunală la pacientul din figura 2

lându-se intraperitoneal. Semnul cel mai precoce al unei perforaţii vezicale este hematuria, pe lângă alte semne de contuzie abdominală (marcă traumatică, distensie abdominală sau sindrom peritonitic în caz de asociere a unei perforaţii digestive). Uneori, o plagă penetrantă abdominală sau pelvină se poate prelungi spre vezica urinară, de aceea, explorarea sub anestezie generală este obligatorie (Fig. 4). Diagnosticul va fi confirmat cu ajutorul ecografiei, cistoscopiei, cistografiei sau al examenului CT. Tratamentul perforaţiilor intraperitoneale constă în sutură în două planuri, prin abord clasic sau laparoscopic. Pentru perforaţiile extraperitoneale, drenajul vezical uretral sau suprapubian poate fi îndeajuns.

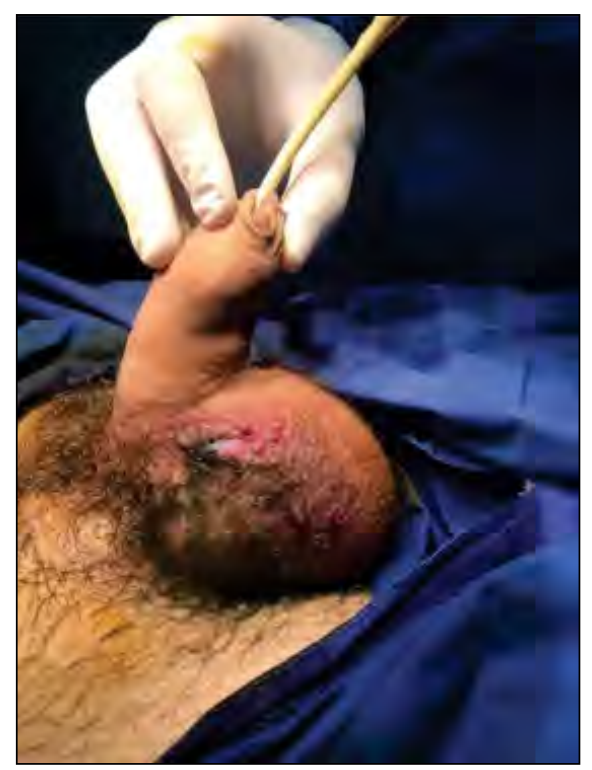

FIGURA 4. Plagă scrotală prin care se elimină albastru de metil introdus pe sonda urinară (perforație de vezică urinară) 
Mortalitatea în cazul traumatismelor abdominale cu perforare de organ cavitar se situează în general în jurul ratei de $10 \%$, fiind cu atât mai mare cu cât leziunile digestive sunt multiple sau asociate cu alte traumatisme $(3,20)$. Cea mai mare rată de morbiditate şi mortalitate se înregistrează în cazul perforaţiilor gastrice, aceste complicaţii crescând paralel cu timpul până la intervenţia chirurgicală: intervenţia în decurs de 2 ore este asociată cu o rată a mortalităţii de $2 \%$, pe când cea efectuată după 24 ore se asociază cu peste $30 \%$ rată a mortalităţii, din cauza combinaţiei dintre şocul septic şi asocierile traumatice (21).

\section{CONCLUZII}

Traumatismele organelor cavitare abdominale la copil reprezintă o patologie cu o frecvenţă şi o severitate în creştere din cauza ritmului alert în care societatea civilă se dezvoltă, cauzele producerii acestor traumatisme fiind in cea mai mare măsură accidentele rutiere. Pentru a reduce la minimum morbiditatea şi mortalitatea acestor leziuni, cunoaşterea mecanismelor de producere, diagnosticarea şi anticiparea evoluţiei leziunilor viscerelor abdominale şi mai ales tratamentul prompt al acestora, în echipă multidisciplinară, în cazul leziunilor ortopedice şi neurochirurgicale asociate, sunt esenţiale.

Conflict of interest: none declared Financial support: none declared

\section{BIBLIOGRAFIE}

1. Klin B, Efrati Y, Vaiman M, Kozer E, Jeroukhimov I, Abu-Kishk I. Abdominal injuries following bicycle-related blunt abdominal trauma in children. Minerva Pediatr. 2016;68(3):167-72.

2. Lynch T, Kilgar J, Al Shibli A. Pediatric Abdominal Trauma. Curr Pediatr Rev. 2018;14(1):59-63.

3. Watts DD, Fakhry SM. EAST Multi-Institutional Hollow Viscus Injury Research Group. Incidence of hollow viscus injury in blunt trauma: an analysis from 275,557 trauma admissions from the East multiinstitutional trial. J Trauma. 2003;54(2):289-294.

4. Abbas AK, Hefny AF, Abu-Zidan FM. Seatbelts and road traffic collision injuries. World J Emerg Surg 2011; 6: 18.

5. Cripps NP, Cooper GJ. Intestinal injury mechanisms after blunt abdominal impact. Ann R Coll Surg Engl 1997; 79: 115-120.

6. Williams MD, Watts $D$, Fakhry $S$. Colon injury after blunt abdominal trauma: Results of the EAST Multi-Institutional Hollow Viscus Injury Study. J Trauma 2003; 55: 906-912.

7. M.R. Aboobakar, J.P. Singh, K. Maharaj et al. Gastric perforation following blunt abdominal trauma. Trauma Case Reports 10. 2017; $12-15$.

8. Losanoea JE, Kjossev KT. Complete traumatic avulsion of the gallbladder. Injury, Int. J. Care Injured.1999; 30: 365-368.

9. Tarcă E, Gavrilescu S. Etiological and clinical-paraclinical implications of acute abdominal pain in children. Rev. Med. Chir. Soc. Med. Nat. 2017; 121(3): 568-576.

10. Nural MS, Yardan T, Güven $\mathrm{H}$ et al. Diagnostic value of ultrasonography in the evaluation of blunt abdominal trauma. Diagn Interv Radiol. 2005;11(1):41-44.

11. Killeen KL, Shanmuganathan K, Poletti PA et al. Helical computed tomography of bowel and mesenteric injuries. J Trauma. 2001;51(1):26-36.
12. Liang T, Roseman E, Gao M, Sinert R. The Utility of the Focused Assessment With Sonography în Trauma Examination in Pediatric Blunt Abdominal Trauma: A Systematic Review and Meta-Analysis. Pediatr Emerg Care. 2019 Mar 12.

13. Aiken DW. Intestinal perforation and facial fracture in an automobile acci-dent victim wearing a seat belt. Journal of the Louisiana State Medical Society 1963;115:235.

14. Roşu VE, Tarcă E, Bădărău OL, Roşu ST. "Binge drinking": Clinical and social aspects in pediatric emergencies - Case presentation. Romanian Journal of Oral Rehabilitation. 2019; 11(1): 121-124.

15. Clendenon JN, Meyers RL, Nance ML et al. Management of duodenal injuries in children. J Pediatr Surg 2004;39:964-968.

16. Biswas S, Adileh M, Almogy G, Bala M. Abdominal injury patterns in patients with seatbelt signs requiring laparotomy. J Emerg Trauma Shock 2014; 7: 295-300.

17. Loveland JA, Boffard KD. Damage control in the abdomen and beyond. Br J Surg 2004; 91: 1,095-1,101.

18. Cheatham ML, Demetriades D, Fabian TC et al. Prospective study examining clinical outcomes associated with a negative pressure wound therapy system and Barker's vacuum packing technique. World J Surg 2013; 37: 2018- 2030.

19. Dokucu Al, Ozdemir E, Oztürk H et al. Urogenital injuries in childhood: A strong association of bladder trauma to bowel injuries. Int Urol Nephrol. 2000;32:3-8.

20. Burch JM. Injury to the colon and rectum. In: Moore EE, Feliciano DV, Mattox KL (eds) Trauma, 5th ed. McGraw Hill, New York. 2004; 735-753.

21. R Maheshwari, A Sayana, P Mahesh. Gastric rupture following blunt trauma abdomen: A case report. Indian J. Clin. Pract. 2013; 23 (12):859-860. 